\title{
The successional status of tropical rainforest tree species is associated with differences in leaf carbon isotope discrimination and functional traits
}

\author{
Damien BONAL ${ }^{\mathrm{a} *}$, Céline BORN ${ }^{\mathrm{a}}$, Claude BRECHET ${ }^{\mathrm{b}}$, Sabrina COSTE, Eric MARCON ${ }^{\mathrm{a}}$, \\ Jean-Christophe RoGGY ${ }^{\mathrm{a}}$, Jean-Marc GUEHL ${ }^{\mathrm{b}}$ \\ ${ }^{\text {a }}$ INRA Kourou, UMR Écologie des Forêts de Guyane, BP 709, 97387 Kourou Cedex, Guyane, France \\ ${ }^{\mathrm{b}}$ INRA Nancy, UMR Écologie et Écophysiologie, 54280 Champenoux, France
}

(Received 24 April 2006; accepted 30 June 2006)

\begin{abstract}
We characterised the among species variability in leaf gas exchange and morphological traits under controlled conditions of seedlings of 22 tropical rainforest canopy species to understand the origin of the variability in leaf carbon isotope discrimination $(\Delta)$ among species with different growth and dynamic characteristics (successional gradient). Our results first suggest that these species pursue a consistent strategy in terms of $\Delta$ throughout their ontogeny (juveniles grown here versus canopy adult trees from the natural forest). Second, leaf $\Delta$ was negatively correlated with WUE and $\mathrm{N}$, and positively correlated with $\mathrm{g}_{\mathrm{s}}$, but among species differences in $\Delta$ were mainly explained by differences in WUE. Finally, species belonging to different successional groups display distinct leaf functional and morphological traits. We confirmed that fast growing early successional species maximise carbon assimilation with high stomatal conductance. In contrast, fast and slow growing late successional species are both characterised by low carbon assimilation values, but by distinct stomatal conductance and leaf morphological features. Along the successional gradient, these differences result in much lower $\Delta$ for the intermediate species (i.e. fast growing late successional) as compared to the two other groups.
\end{abstract}

${ }^{13} \mathrm{C}$ / functional diversity / leaf gas exchange / species grouping / tropical rainforest

Résumé - Le statut successionnel des espèces de la forêt tropicale humide est associé à des différences de discrimination isotopique du carbone et de traits fonctionnels foliaires. Nous avons caractérisé la variabilité interspécifique des échanges gazeux et des traits morphologiques foliaires en conditions environnementales contrôlées de jeunes plants de 22 espèces d'arbres de la canopée en forêt tropicale humide afin de comprendre l'origine de la variabilité de la discrimination isotopique du carbone foliaire $(\Delta)$ observée entre ces espèces présentant des caractéristiques de croissance et de dynamique distinctes (groupes successionnels). Nous montrons premièrement que les espèces tropicales possèdent une stratégie très conservée de $\Delta$ au cours de leur ontogénie (juvéniles élevés ici versus arbres adultes de la canopée en forêt naturelle). Deuxièmement, $\Delta$ était négativement corrélée à WUE et $\mathrm{N}$, et positivement à $\mathrm{g}_{\mathrm{s}}$, mais les différences de $\Delta$ entre espèces sont principalement expliquées par des différences de WUE. Enfin, nous montrons que les espèces appartenant à des groupes successionnels distincts présentent des traits fonctionnels et morphologiques foliaires distincts. Nous confirmons que les espèces à croissance rapide qui s'installent en premier au cours de la succession écologique (FE) maximisent A avec de fortes conductances stomatiques. Les espèces climax (qui s'installent en second dans la succession écologique), à croissance rapide (FL) ou à croissance faible (SL), présentent des valeurs de A identiques, mais des valeurs de $\mathrm{g}_{\mathrm{s}}$ ainsi que des caractéristiques morphologiques foliaires distinctes. Dans la succession écologique, ces différences se traduisent par des valeurs de $\Delta$ nettement plus faibles pour les espèces intermédiaires (c'est-à-dire les espèces climax à croissance rapide) par rapport aux deux autres groupes.

${ }^{13} \mathrm{C}$ / diversité fonctionnelle / échanges gazeux foliaires / groupes successionnels / forêt tropicale humide

\section{INTRODUCTION}

In an attempt to simplify the complexity of the tropical rainforest ecosystem and to understand the mechanisms underlying the coexistence and distribution of the numerous tree species, forest ecologists have tried to group species according to ecological traits $[3,15,39,50,55,58]$. A continuum of trait values, rather than distinct classes, is usually found and the chance to find a single clustering of species based on several ecological traits is small. However, classifications combining at least two ecological axes have been proposed [22,24,39,55]. These axes can be characterised by the dynamic of the forest

\footnotetext{
*Corresponding author: damien.bonal@kourou.cirad.fr
}

(tree growth, mortality and recruitment) and the morphology of trees (height and maximal diameter of the trees) and are pertinent to understand ecosystem processes [38].

Distinct leaf functional and/or morphological traits have been found among successional groups in neotropical rainforests $[3,6,15,16,30,42,44,49]$. Comparisons between fast growing early successional species (FE) and late successional species at a whole have been widely conducted. Higher specific leaf area (SLA), leaf dry mass based nitrogen concentration values $(\mathrm{N})$ or maximum photosynthetic characteristics (A) are generally found in the former ones. In contrast, comparisons within the late successional group (fast growing late successional, FL, versus slow growing late successional, SL) 
are more scarce. Whereas no significant differences in photosynthetic capacities among these two groups were observed in a common garden experiment [10], higher values of $\mathrm{A}$ and $\mathrm{N}$ were found in FL species (defined as "intermediate") as compared to SL ones in an in situ experiment on saplings in BCI, Panama [15]. Furthermore, sunlit leaf carbon isotope discrimination $(\Delta)$ of adult trees was lower in FL species as compared to SL and FE species in different tree communities in French Guiana [7, 26], underlying an original non-linear distribution (modal distribution) of this trait along the successional gradient. Carbon isotope discrimination $(\Delta)$ - roughly the difference in carbon isotope composition $\left(\Delta^{13} C\right)$ between the carbon source for photosynthesis (i.e. atmospheric $\mathrm{CO}_{2}$ ) and the photosynthetic products (i.e. leaf material) - is a convenient measure of long-term intercellular $\mathrm{CO}_{2}$ concentration [19-21]. It constitutes an indicator of the set point for leaf gas exchange regulation, reflecting leaf-level water-use efficiency (WUE) and overall trade-offs between carbon gain and transpirational water loss [13]. The physiological basis for these differences in $\Delta$ among successional groups has not yet been elucidated.

While screening tree communities in the tropical rainforest of French Guiana, variations in sunlit leaf $\Delta$ of up to $6.5 \%$ have been found within 1-ha stands [7]. This variation reflects a threefold variation in WUE among species. WUE is defined as the ratio of net carbon assimilation rate (A) to stomatal conductance for water vapour $\left(\mathrm{g}_{\mathrm{s}}\right)$. Yet it remains unclear whether estimates of $\Delta$-derived WUE are related to differences in $\mathrm{A}$ or $\mathrm{g}_{\mathrm{s}}$, or merely reflect differences in the trade-off between these variables $[13,21]$. A large variability in such leaf gas exchange characteristics has been observed among juveniles of tropical rainforest species, with up to a four-fold range among species within the same environment [3, 6, 9, 15-17, 29, 30, 32, 37, 54]. Furthermore, based on observations on seven species growing under homogenous conditions in monospecific plantations, it has been suggested that differences in $\Delta$ among tropical rainforest tree species were mainly related to differences in $g_{s}$ [26]. Species with low $\Delta$ values presented low $g_{s}$ values, while $\mathrm{A}$ values were intermediate. We question here whether species belonging to different successional groups and differing in $\Delta$ would display different leaf gas exchange $\left(\mathrm{A}, \mathrm{g}_{\mathrm{s}}, \mathrm{WUE}\right)$ and leaf morphological traits. In particular, we address the following questions:

- Are differences among species in $\Delta$ consistent over ontogenetic stages (juvenile versus adult)?

- Is the among species variability in $\Delta$ in tropical rainforests related to differences in leaf gas exchange $\left(\mathrm{A}, \mathrm{g}_{\mathrm{s}}\right.$, or merely the ratio $\mathrm{A} / \mathrm{g}_{\mathrm{s}}=\mathrm{WUE}$ ) and with other related leaf traits?

- Are species belonging to different successional groups (FE, FL, SL) characterised by different leaf morphological and/or functional characteristics, particularly $\Delta$, under common environmental conditions?

\section{MATERIALS AND METHODS}

\subsection{Plant material}

In situ comparative leaf gas exchange measurements on numerous adult trees under similar environmental conditions are not fea- sible. Then, in this study, potted seedlings of 22 abundant canopy tree species of the rainforest of French Guiana were grown in a glasshouse under common environmental conditions. The 22 focal species represented a broad range of in situ leaf $\Delta$ ([7], and Bonal, unpublished data) and were classified into three successional groups with regard to growth and dynamic characteristics according to Favrichon $[22,23]$. This grouping is based on a statistical analysis of tree dynamic (growth, mortality and recruitment) and morphological and dendrometric (height and maximal diameter of the trees) variables at the adult and sub-adult stage and a PCA analysis leading to two axes related to potential size and heliophily. The three groups are fast growing early successional (FE), fast growing late successional (FL), and slow growing late successional (SL), with mean canopy tree annual diameter increments equal to $0.27 \pm 0.04,0.24 \pm 0.03$, and $0.13 \pm 0.01 \mathrm{~cm} \mathrm{year}^{-1}$, respectively [22,23]. SL species regenerate and develop in the understory and retain low diameter growth rates even once installed in the canopy. In contrast, FL species display higher growth rates in the large diameter classes than in the small diameter ones. For species not included in these analyses, the successional group was assigned based on Béna [4]. No such information was found for Eriotheca.

Fifty seeds per species were collected from within a 10-m radius of each of at least five adult trees per species in the Paracou forest, French Guiana $\left(5^{\circ} 16^{\prime} \mathrm{N}, 52^{\circ} 55^{\prime} \mathrm{W}\right)$ in spring 2000, except for Cecropia and Talisia for which seeds were collected in the surroundings of Kourou, French Guiana. Randomly selected germinated seedlings (15-20 per species) were kept for 18 months in 5.3-L black polyethylene containers filled with a homogenised forest soil in a shaded understory site (about 16\% full sun). In September 2001, 1012 seedlings per species were transplanted into 20 -L plastic pots and randomly distributed in a glasshouse in Kourou, French Guiana. One layer of neutral shade-cloth was used to reduce light levels to about $25 \%$ of full sun (maximum PAR $\approx 500 \mu \mathrm{mol} \mathrm{m}^{-2} \mathrm{~s}^{-1}$ ). Pots were filled with a mixture of sand (30\%) and an A-horizon soil (70\%) from the Paracou forest. Plantlets were grown for eight months, during which they were watered every two days in order to match the amount of water observed to have been lost through evapotranspiration and then to maintain plants at field capacity $\left(\approx 0.25 \mathrm{~m}^{3} \mathrm{~m}^{-3}\right)$. Soil water content in the pots was recorded monthly using a TDR Trime FM2 (Imko, Ettlingen, Germany). Pots were fertilised every second month (5 g complete fertiliser per pot, $12 / 12 / 17 / 2 \mathrm{~N} / \mathrm{P} / \mathrm{K} / \mathrm{Mg}$ ) and treated with a commercial insecticide (Cuberol: $5 \%$ rotenone).

\subsection{Leaf gas exchange, leaf and plant traits}

In April 2002, leaf gas exchange measurements were conducted on 7-11 plants per species using a portable photosynthesis system (CIRAS1, PP-Systems, Hoddesdon, UK) operating in open mode and fitted with a Parkinson leaf cuvette. Gas exchange measurements were conducted on two leaves per plant under the following nonlimiting environmental conditions [10]: $[\mathrm{CO} 2]=360 \mathrm{ppm}$; PAR = $670 \pm 20 \mu \mathrm{mol} \mathrm{m} \mathrm{m}^{-2} \mathrm{~s}^{-1}$; vapour pressure deficit $=1.2 \pm 0.4 \mathrm{kPa}$; air temperature $=30.0 \pm 2.1{ }^{\circ} \mathrm{C}$. Equations of Caemmerer and Farquhar [8] were used to calculate net carbon assimilation rate on a leaf area (A, $\mu \mathrm{mol} \mathrm{m} \mathrm{m}^{-2} \mathrm{~s}^{-1}$ ) or mass $\left(\mathrm{A}_{\mathrm{m}}, \mathrm{mmol} \mathrm{g}^{-1} \mathrm{~s}^{-2}\right)$ basis, stomatal conductance for water vapour $\left(\mathrm{g}_{\mathrm{s}}, \mathrm{mol} \mathrm{m}^{-2} \mathrm{~s}^{-1}\right)$ and intrinsic water-use efficiency (WUE $=\mathrm{A} / \mathrm{g}_{\mathrm{s}}$ ). After the gas exchange measurements, 10 to 15 mature and fully expanded leaves per plant were collected in order to characterise specific leaf area (SLA, $\mathrm{cm}^{2} \mathrm{~g}^{-1}$ ) and leaf thickness $(\mathrm{LT}, \mu \mathrm{m})$ and calculate leaf density (LD $=1 /$ (SLA 
$\times \mathrm{LT}), \mathrm{g} \mathrm{cm}^{-3}$ ). The leaves were then dried for $48 \mathrm{~h}$ at $70.0{ }^{\circ} \mathrm{C}$ and finely ground.

\subsection{Carbon, nitrogen and isotope analyses}

A sub-sample of $10^{-3} \mathrm{~g}$ of dry leaf powder was analysed for total carbon $(\mathrm{C}, \%)$ and nitrogen $\left(N, \mathrm{mg} \mathrm{g}^{-1}\right)$ concentration (ThermoQuestNA-1500-NCS, Carlo Erba, Italy) at the stable isotope facility of INRA Nancy, France. Leaf carbon isotope composition $\left(\delta^{13} \mathrm{C}\right)$ for each plant was estimated on the same sub-sample using an isotope ratio mass spectrometer (Delta-S Finnigan Mat, Bremen, Germany). Glasshouse air carbon isotope composition $\left(\delta_{a}=-7.85 \%\right.$ ) was estimated using leaf carbon isotope composition $\left(\delta^{13} \mathrm{C}\right)$ of corn grown for four months during the acclimation phase in the glasshouse [35]. Leaf carbon isotope discrimination $(\Delta)$ was calculated as:

$$
\Delta=\frac{\delta_{\mathrm{a}}-\delta^{13} C}{1+0.001 \times \delta^{13} \mathrm{C}}
$$

$\Delta$ is theoretically related with WUE $\left(=\mathrm{A} / \mathrm{g}_{\mathrm{s}}\right)$ through the following equation [19]:

$$
\Delta=b-\frac{1.6 \times(b-a) \times \mathrm{WUE}}{\mathrm{C}_{\mathrm{a}}},
$$

where $\mathrm{C}_{\mathrm{a}}$ is the $\mathrm{CO}_{2}$ concentration in air, and $a$ and $b$ are fractionation factors during the diffusion of $\mathrm{CO}_{2}$ through the stomata and during photosynthetic carboxylation, respectively, that are assumed here to be constant for all species.

\subsection{Ontogenetic test}

To compare leaf $\Delta$ of seedlings grown in the glasshouse (original data of this study) with that of sunlit leaves of mature canopy trees, we compiled $\Delta$ data from two 1-ha stands (Saint-Elie [7], and Bafog, Bonal, unpublished data) in French Guiana. These two stands comprised 3-9 mature and dominant trees characterised for leaf $\Delta$ for 14 species out of the 22 studied species in the glasshouse (Tab. I). For more details on data collecting protocol, see Bonal et al. [7].

\subsection{Statistical analyses}

Statistical analyses were performed using SAS programs (SASInstitute, Cary, USA). Differences among species for the different parameters were tested using ANOVA in the general linear regression model (GLM) procedure. Correlations between the different parameters were tested using Pearson's correlation coefficients. The relationship between $\Delta$ and WUE was tested using a general linear regression model. As both sets of juvenile and adult $\Delta$ data were subjected to measurements errors, a model II regression analysis was performed to test for any relationship between glasshouse and forest values among the 14 species. Statistical differences among successional groups were tested using an ANOVA and post-hoc Duncan's multiple range tests.

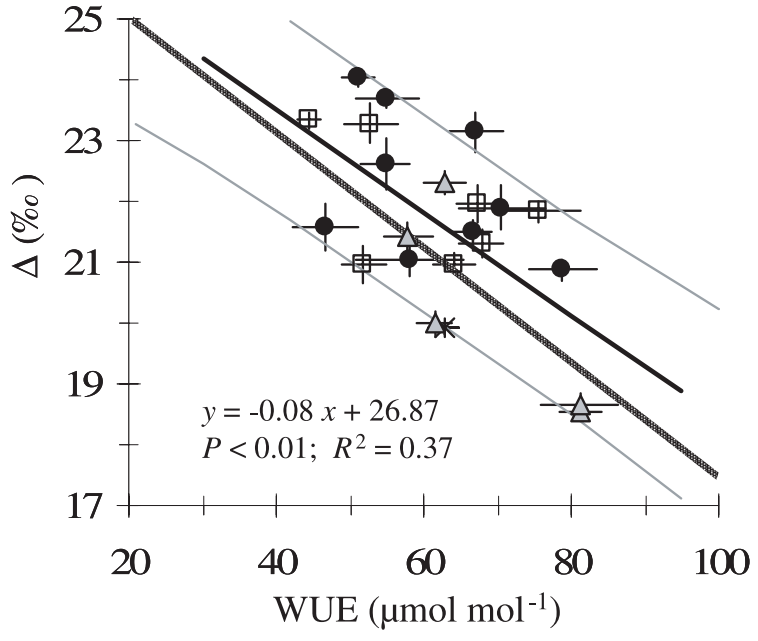

Figure 1. The relationship between leaf carbon isotope discrimination $(\Delta)$ and intrinsic water-use efficiency (WUE $=\mathrm{A} / \mathrm{g}_{\mathrm{s}}$ ) for potted seedlings of 22 tropical rainforest species grown in non-limiting environmental conditions in a glasshouse ( $n=7$ to 11 plants per species). The theoretical relationship is represented by the dotted line $(\Delta=-0.095 \times$ WUE +27.00$)$ [21]. Vertical and horizontal bars denote \pm 1 standard error of the species mean. The grey lines represent the upper and lower confidence interval limits (95\%) of the relationship between $\Delta$ and WUE. The Symbols correspond to the successional groups: white squares correspond to fast growing early successional species (FE); grey triangles correspond to fast growing late successional species (FL); black dots correspond to slow growing late successional species (SL); the star corresponds to an undetermined species.

\section{RESULTS}

Mean species $\Delta$ varied from 18.6 to $24.0 \%$, with low within species variability (Fig. 1). WUE, SLA and N varied over a twofold range (Fig. 1, Tab. I). A, g and LD varied over a threefold range.

For the significant statistical correlations obtained among measured parameters (Tab. II), we underline that $A$ or $A_{m}$ were significantly correlated with all parameters except $\Delta$ and WUE. $\Delta$ was negatively correlated with WUE and $g_{s}$ and positively with $\mathrm{N}$. WUE and $\mathrm{g}_{\mathrm{s}}$ were strongly negatively correlated.

The relationship between $\Delta$ and WUE was highly significant (Fig. 1). This relationship was not statistically different from the one described by the theory since the slope and the $y$-intercept of the theoretical line $(-0.095$ and 27.00 , respectively) fell in the confidence interval (95\%) of the slope $(-0.084 \pm 0.024)$ and the $y$-intercept $(26.87 \pm 1.56)$ of the relationship between $\Delta$ and WUE.

There was a strong positive and linear relationship between $\Delta$ of sunlit leaves of dominant canopy trees and the leaves of potted seedlings of the same species grown in the glasshouse $(P<0.01)$ (Fig. 2).

There was a significant group effect on all studied traits (Fig. 3) except LD $(P=0.23)$. FE species had highest values in $A_{m}, A, g_{s}, N$ and SLA. There was no difference in $A_{m}$ or $A$ 
Table I. Mean ( \pm SE, $n=7-11)$ of specific leaf area $\left(\mathrm{SLA}, \mathrm{cm}^{2} \mathrm{~g}^{-1}\right)$, leaf density $\left(\mathrm{LD}, \mathrm{g} \mathrm{cm}^{-3}\right)$, leaf carbon concentration $(\mathrm{C}, \%)$, and nitrogen concentration on a dry mass basis $\left(\mathrm{N}, \mathrm{mg} \mathrm{g}^{-1}\right)$ of the 22 studied species. Species are sorted according to successional groups (FE $=$ fast growing early successional, $\mathrm{FL}=$ fast growing late successional, $\mathrm{SL}=$ slow growing late successional, Und. = Undetermined). * Symbol indicates that this species was included in the juvenile versus adult comparison. Groups' effect was tested using an ANOVA and post-hoc Duncan's multiple range test $(P<0.05)$. Species named according to Boggan et al. [5].

\begin{tabular}{|c|c|c|c|c|c|c|}
\hline Species name & $\begin{array}{l}\text { Taxonomic } \\
\text { family }\end{array}$ & Group & $\begin{array}{l}\text { SLA } \\
\mathrm{cm}^{2} \mathrm{~g}^{-1}\end{array}$ & $\begin{array}{l}\mathrm{LD} \\
\mathrm{g} \mathrm{cm}^{-3}\end{array}$ & $\begin{array}{l}\mathrm{C} \\
\%\end{array}$ & $\begin{array}{l}\mathrm{N} \\
\mathrm{mg} \mathrm{g}^{-1}\end{array}$ \\
\hline Bagassa guianensis J.B. Aublet & Moraceae & $\mathrm{FE}$ & $255.6 \pm 48.5$ & $0.18 \pm 0.02$ & $46.3 \pm 1.8$ & $24.9 \pm 1.7$ \\
\hline * Carapa procera A.P. De Candolle & Meliaceae & FE & $158.6 \pm 6.6$ & $0.30 \pm 0.01$ & $48.2 \pm 0.2$ & $17.9 \pm 0.6$ \\
\hline * Cecropia obtusa Trécul & Moraceae & FE & $215.1 \pm 9.6$ & $0.19 \pm 0.01$ & $47.2 \pm 0.4$ & $21.1 \pm 1.5$ \\
\hline Hymenaea courbaril Linnaeus & Caesalpiniaceae & FE & $199.8 \pm 32.0$ & $0.34 \pm 0.04$ & $48.6 \pm 0.6$ & $24.8 \pm 0.9$ \\
\hline Tabebuia insignis Sandwith & Bignoniaceae & $\mathrm{FE}$ & $138.9 \pm 5.9$ & $0.31 \pm 0.02$ & $48.4 \pm 0.3$ & $21.4 \pm 1.3$ \\
\hline * Virola michelii Heckel & Myristicaceae & FE & $129.1 \pm 5.5$ & $0.45 \pm 0.01$ & $49.8 \pm 0.3$ & $18.5 \pm 0.6$ \\
\hline Virola surinamensis Warburg & Myristicaceae & $\mathrm{FE}$ & $142.9 \pm 5.5$ & $0.33 \pm 0.02$ & $51.6 \pm 0.3$ & $23.1 \pm 0.5$ \\
\hline * Dicorynia guianensis G.J. Amshoff & Caesalpiniaceae & FL & $188.5 \pm 10.4$ & $0.27 \pm 0.02$ & $51.1 \pm 0.3$ & $19.8 \pm 0.9$ \\
\hline * Eperua falcata J.B. Aublet & Caesalpiniaceae & FL & $140.6 \pm 5.0$ & $0.43 \pm 0.00$ & $50.9 \pm 0.4$ & $23.7 \pm 0.9$ \\
\hline * Eperua grandiflora Bentham & Caesalpiniaceae & FL & $117.0 \pm 13.2$ & $0.44 \pm 0.00$ & $49.6 \pm 0.3$ & $20.3 \pm 1.2$ \\
\hline * Sextonia rubra & Lauraceae & FL & $107.1 \pm 6.2$ & $0.36 \pm 0.01$ & $50.1 \pm 0.4$ & $11.5 \pm 0.6$ \\
\hline Talisia furfuracea Sandwith & Sapindaceae & FL & $208.6 \pm 9.3$ & $0.34 \pm 0.04$ & $48.4 \pm 0.3$ & $21.8 \pm 0.7$ \\
\hline Amanoa guianensis J.B. Aublet & Euphorbiaceae & SL & $112.6 \pm 6.0$ & $0.35 \pm 0.02$ & $47.4 \pm 1.2$ & $15.0 \pm 1.1$ \\
\hline * Aspidosperma album $\mathrm{R}$. Benoist & Apocynaceae & SL & $142.9 \pm 7.7$ & $0.31 \pm 0.02$ & $49.0 \pm 0.8$ & $14.4 \pm 1.4$ \\
\hline * Eschweilera sagotiana Miers & Lecythidaceae & SL & $101.0 \pm 5.1$ & $0.36 \pm 0.03$ & $49.3 \pm 0.3$ & $15.6 \pm 0.9$ \\
\hline * Lecythis persistens Sagot & Lecythidaceae & SL & $107.0 \pm 7.5$ & $0.37 \pm 0.03$ & $50.9 \pm 0.2$ & $15.7 \pm 0.8$ \\
\hline * Licania heteromorpha Bentham & Chrysobalanaceae & SL & $102.0 \pm 7.5$ & $0.41 \pm 0.03$ & $48.5 \pm 0.7$ & $10.4 \pm 0.8$ \\
\hline * Manilkara bidentata A.J. Chevalier & Sapotaceae & SL & $94.9 \pm 8.5$ & $0.32 \pm 0.02$ & $47.6 \pm 1.2$ & $11.7 \pm 0.9$ \\
\hline Poraqueiba guianensis J.B. Aublet & Icacinaceae & SL & $100.4 \pm 5.5$ & $0.37 \pm 0.02$ & $49.2 \pm 0.3$ & $10.7 \pm 0.5$ \\
\hline * Protium subseratum Engler & Burseraceae & SL & $154.8 \pm 10.9$ & $0.35 \pm 0.03$ & $47.5 \pm 0.2$ & $14.4 \pm 0.5$ \\
\hline * Vouacapoua americana J.B. Aublet & Caesalpiniaceae & SL & $161.8 \pm 4.4$ & $0.45 \pm 0.01$ & $51.5 \pm 0.4$ & $18.6 \pm 0.6$ \\
\hline Eriotheca sp. & Bombacaceae & Und. & $98.2 \pm 5.9$ & $0.25 \pm 0.01$ & $46.0 \pm 0.3$ & $15.9 \pm 0.7$ \\
\hline ANOVA-Test for group effect & & & $P<0.001$ & $P=0.230$ & $P<0.001$ & $P<0.001$ \\
\hline
\end{tabular}

between FL and SL species. In contrast, N, C and SLA were significantly higher in FL species as compared to FE ones, and $\mathrm{g}_{\mathrm{s}}$ was lower in FL species as compared to FE ones. FL species displayed significantly higher WUE and lower $\Delta$ as compared to FE and SL species, which did not differ.

\section{DISCUSSION}

\subsection{Functional diversity}

This study confirmed the high variability of leaf morphological $[46,56]$ and functional $[6,15,17,29,30,32,46]$ traits among tropical rainforest species. In common environmental conditions, we observed differences on a two-to-three-fold range among species in leaf gas exchange, WUE, and leaf morphological characteristics, whereas the within species variability of these traits under homogenous conditions remains low (Tab. I, Fig. 1).
The relationship between time-integrated $\Delta$ and instantaneous WUE at the species level $(\Delta=-0.084 \times \mathrm{WUE}+26.87$; $\left.P<0.01 ; R^{2}=0.37\right)$ was in agreement with the two-step carbon isotope discrimination model [19] $(\Delta=-0.095 \times \mathrm{WUE}+$ 27.00) (Fig. 1). The relationship for some species slightly deviated from the theoretical line. As already discussed by other authors $[19,41]$, the difference in time-integration scale between the two variables could be one major cause for this discrepancy. Whereas WUE was derived from spot measurements of instantaneous leaf gas exchange, $\Delta$ was estimated based on leaf carbon isotope composition that are integrated over the lifetime of the analysed leaf tissue (9 to 24 months). Other causes related to differences in morphology and structure of the leaves of these species (leaf density, specific leaf area, Tab. I) must be considered as well $[20,28,40]$. These differences could lead to distinct values of internal conductance to diffusion of $\mathrm{CO}_{2}$ from the intercellular air spaces to the sites of carboxylation and then to internal isotopic fractionation factors differing among species [18]. Furthermore, recent papers 


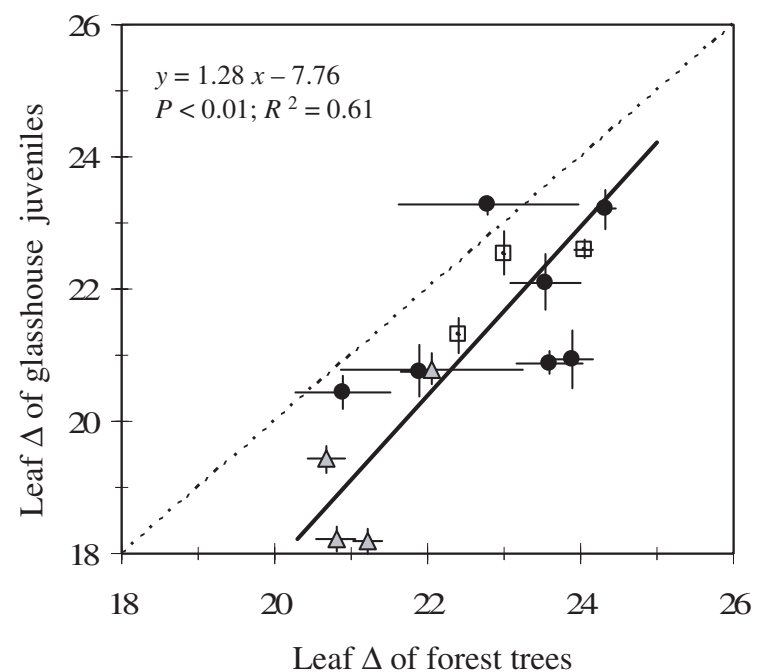

Figure 2. The relationship (Model II regression) between mean species leaf $\Delta$ values $(n=14)$ of seedlings grown in the glasshouse and of canopy trees from two forest stands in French Guiana. For the seedlings, species mean is based on 7-11 plants. For the adult trees, species mean is based on 3-9 trees. Vertical and horizontal bars denote \pm 1 standard error of the mean. Symbols correspond to the successional groups: white squares correspond to fast growing early successional species (FE); grey triangles correspond to fast growing late successional species (FL); black dots correspond to slow growing late successional species (SL).

Table II. Pearson correlation coefficients among morphological and functional parameters for the 22 studied species: leaf-area based rates of net carbon assimilation (A, $\mu \mathrm{mol} \mathrm{m} \mathrm{m}^{-2} \mathrm{~s}^{-1}$ ), leaf-mass based rates of net carbon assimilation $\left(\mathrm{A}_{\mathrm{m}}, \mu \mathrm{mol} \mathrm{s}{ }^{-1} \mathrm{~g}^{-1}\right)$, stomatal conductance for water vapour $\left(\mathrm{g}_{\mathrm{s}}, \mathrm{mol} \mathrm{m}^{-2} \mathrm{~s}^{-1}\right)$, intrinsic water-use efficiency $(\mathrm{WUE}=$ $\mathrm{A} / \mathrm{g}_{\mathrm{s}}$ ), leaf carbon isotope discrimination during photosynthesis $(\Delta)$, leaf carbon concentration $(\mathrm{C}, \%)$, leaf nitrogen concentration on a dry mass basis $\left(\mathrm{N}, \mathrm{mg} \mathrm{g}^{-1}\right)$, specific leaf area (SLA, $\mathrm{cm}^{2} \mathrm{~g}^{-1}$ ), and leaf density $\left(\mathrm{LD}, \mathrm{g} \mathrm{cm}^{-3}\right)$. Numbers in bold indicate significant correlation at $P=0.05$.

\begin{tabular}{lcccccccc}
\hline & $\mathrm{A}_{\mathrm{m}}$ & $\mathrm{g}_{\mathrm{s}}$ & WUE & $\Delta$ & $\mathrm{C}$ & $\mathrm{N}$ & $\mathrm{SLA}$ & $\mathrm{LD}$ \\
\hline $\mathrm{A}$ & $\mathbf{0 . 6 3}$ & $\mathbf{0 . 7 9}$ & 0.07 & -0.03 & $\mathbf{- 0 . 2 3}$ & $\mathbf{0 . 3 6}$ & $\mathbf{0 . 2 3}$ & $\mathbf{- 0 . 4 1}$ \\
$\mathrm{A}_{\mathrm{m}}$ & & $\mathbf{0 . 6 2}$ & -0.17 & 0.23 & -0.24 & $\mathbf{0 . 4 9}$ & $\mathbf{0 . 7 9}$ & $\mathbf{- 0 . 5 8}$ \\
$\mathrm{g}_{\mathrm{s}}$ & & & $\mathbf{- 0 . 4 9}$ & $\mathbf{0 . 2 4}$ & $\mathbf{- 0 . 2 9}$ & 0.11 & $\mathbf{0 . 2 7}$ & $\mathbf{- 0 . 4 7}$ \\
WUE & & & & $\mathbf{- 0 . 5 1}$ & $\mathbf{0 . 1 9}$ & $\mathbf{0 . 3 7}$ & -0.10 & $\mathbf{0 . 2 9}$ \\
$\Delta$ & & & & & -0.06 & $\mathbf{- 0 . 3 1}$ & 0.11 & 0.04 \\
$\mathrm{C}$ & & & & & & 0.12 & -0.07 & $\mathbf{0 . 3 7}$ \\
$\mathrm{N}$ & & & & & & & $\mathbf{0 . 5 1}$ & -0.05 \\
SLA & & & & & & & & $\mathbf{- 0 . 5 3}$ \\
\hline
\end{tabular}

pointed to variable isotopic fractionations during dark respiration (e.g. [51]) or post-photosynthetic fractionations [1]. These fractionations, that are not included in the simple model of discrimination described in [19] and used here, could differ among species and contribute to the shift with the theoretical line.
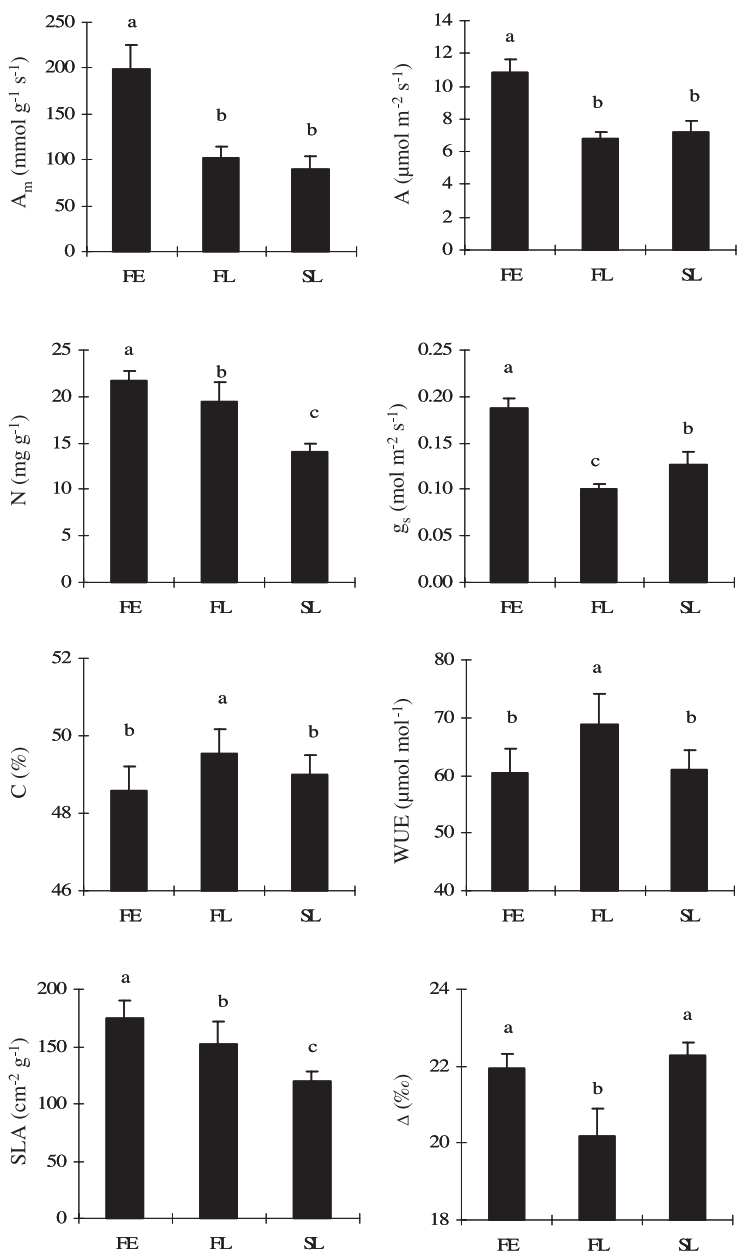

Figure 3. The mean values ( $\pm 1 \mathrm{SE}$ ) of mass-based carbon net assimilation $\left(\mathrm{A}_{\mathrm{m}}\right)$, leaf area-based carbon net assimilation $(\mathrm{A})$, leaf nitrogen concentration on a dry mass basis $(\mathrm{N})$, stomatal conductance for water vapour $\left(\mathrm{g}_{s}\right)$, leaf carbon concentration $(\mathrm{C})$, intrinsic water-use efficiency $\left(\right.$ WUE $=\mathrm{A} / \mathrm{g}_{\mathrm{s}}$ ), specific leaf area (SLA), and leaf carbon isotope discrimination $(\Delta)$ for each successional groups $(\mathrm{FE}=$ fast growing early successional, $\mathrm{FL}=$ fast growing late successional, $\mathrm{SL}=$ slow growing late successional) for potted seedlings of 22 species of the rainforest of French Guiana grown in a glasshouse under nonlimiting environmental conditions. For a given trait, means followed by the same letter are not significantly different at $P=0.05$ (Duncan's multiple range test).

When grown in pots under homogeneous environmental conditions, the 22 focal species almost covered the entire gradient in $\Delta$ observed in 1-ha stands of natural forest for mature trees $(5.4)$ $[7,26]$. Furthermore, a significant correlation between $\Delta$ of 2-year old seedlings and canopy trees was found $\left(\Delta_{\text {juvenile }}=1.28 \times \Delta_{\text {adult }}-7.76 ; P<0.01 ; R^{2}=0.61\right.$, Fig. 2$)$ and then an overall consistent species ranking. Several studies demonstrated ontogenetic shifts for functional traits such as biomass allocation, SLA or A for tropical $[36,43,53]$ or temperate (e.g. [11]) species, whereas no such shift was observed for hydraulic traits for Patagonian conifers [27]. Our results support the statement that among species differences in 
the metabolic intrinsic set point for the trade-off between carbon and water fluxes at the leaf level, as reflected by $\Delta[13]$, are maintained over the lifetime of these species. Except for one species, leaf $\Delta$ of glasshouse seedlings were lower (1.5\%o on average) than values of adult trees (Fig. 2), which can be interpreted as a higher WUE for juveniles as compared to trees (see Eq. (1)). These differences can be mainly explained by the differences in environmental conditions (i.e. light, air temperature and humidity, $\mathrm{CO}_{2}$ concentration) encountered by the two considered sets of values. These conditions are recognised to strongly influence $\Delta$ (see synthesis in [14]). Furthermore, isotope fractionations come into play during carbohydrate storage and translocation, or when leaf tissues are partially constructed from stored carbohydate reserves, as for adult trees [52].

\subsection{Association of traits}

Previous studies on trade-offs among leaf traits concentrated mainly on traits related to carbon assimilation, leaf structure or chemical concentrations $[45,46,56,57]$. Leaf carbon traits of tropical rainforest seedlings studied here were in agreement with general trade-offs since carbon assimilation increases with increasing $\mathrm{N}$ and SLA, and decreases with increasing $\mathrm{C}$ and LD (Tab. II). It has been suggested that including additional traits related to water relations (e.g. leaf conductance to water vapour) in these approaches may improve our understanding of plant function $[48,57]$. We present here evidence that other associations of traits at the leaf level do exist among tropical rainforest species with regard to carbon isotope discrimination and stomatal regulation (Tab. II). Higher $\Delta$ are associated with lower WUE and $g_{s}$, and higher N. Furthermore, higher $\mathrm{A}$ or $\mathrm{A}_{m}$ are strongly associated with $\mathrm{g}_{\mathrm{s}}$. These data suggest that biophysical and natural selection constraints result in the exclusion of some combinations between transpirational fluxes and leaf structure or carbon concentrations. Including these functional traits in larger meta-analyses on leaf economics may therefore allow improvements of the interpretation of functional differences among tropical rainforest tree species.

In order to understand the origin of the strong variability in $\Delta$ among species, we compared the leaf gas exchange and morphological traits of these species. Differences among species in $\Delta$ were not accounted for by differences in photosynthetic characteristics, but rather by differences in $g_{s}$ and WUE (Tab. II, Fig. 1), in agreement with previous observations on tropical rainforest species $[6,26]$. However, although the relationship between $\Delta$ and $g_{s}$ was statistically significant (Tab. II), $g_{\mathrm{s}}$ explained only a very small part of the variability in $\Delta$ among species $\left(R^{2}=0.08\right)$. In contrast, WUE explained $37 \%$ of this variability (Fig. 1). Therefore, we suggest that it is the compromise between carbon fluxes and stomatal conductance for water vapour, i.e. WUE, rather than $\mathrm{A}$ or $\mathrm{g}_{\mathrm{s}}$, that is the main determinant for the differences among tropical rainforest species in $\Delta$ (Fig. 1). High $\Delta$ in some species are associated with low WUE, and vice versa. Such comparative studies on a large number of tropical rainforest species have not yet been conducted. Nevertheless, correlations between $\Delta$ and $\mathrm{A}$ or $\mathrm{g}_{\mathrm{s}}$ have been observed in other forested ecosystems, with contrasting patterns. Differences in $\Delta$ among evergreen species from Japanese warm-temperate forests were not caused by the variation in $\mathrm{g}_{\mathrm{s}}$, but mainly by the difference in long-term photosynthetic capacity [28]. The variability in WUE among Caribbean hybrid Pine clones was also mainly attributed to differences in photosynthetic capacity rather than in stomatal conductance [59].

\subsection{Differences among groups}

Our results pointed to significant differences in $\Delta$, leaf gas exchange, and leaf characteristics among seedlings of species belonging to different successional groups (Fig. 3) that are consistent with other studies (e.g. [3, 15, 30, 32]).

Fast growing early successional species (FS) tend to maximise carbon assimilation rates (highest A) with stomata widely open (highest $g_{s}$ ) for high transpiration rates. This strategy is associated with higher SLA, N, $\mathrm{A}_{\mathrm{m}}, \mathrm{A}$ or $\mathrm{g}_{\mathrm{s}}$ values than those of the late successional species, and high $\Delta$ (21.9) and low WUE $\left(60.5 \mu \mathrm{mol} \mathrm{mol}{ }^{-1}\right)$. Furthermore, we present evidence for the existence of two distinct groups within the late successional species (fast growing versus slow growing) with regard to leaf functional and morphological traits, supporting previous studies under natural conditions [15]. The two groups are characterised by non-significantly different carbon assimilation rates $\left(A_{m}\right.$ or $\left.A\right)$, but FL species have lower $g_{s}$ and higher SLA, C and N than SL species (Fig. 3). Furthermore, the strategy of the FL species in the trade-off between A and $\mathrm{g}_{\mathrm{s}}$ seems to be associated with much lower $\Delta(20.2 \%)$ values than SL ones $(22.3 \%$ ). The observed differences among these groups in $\Delta$ seem to be environmentally stable since our results for seedlings grown in a glasshouse are in agreement with previous studies on sunlit leaves of forest trees under natural conditions $[7,26]$. These functional differences seem to be consistent with the suggested adaptations of tropical rainforest species to the numerous and complex ecological niches related to light and water acquisition [47].

In contrast with most leaf functional traits, we demonstrated here the absence of a linear distribution in $\triangle$, WUE and $\mathrm{C}$ along the successional gradient (Fig. 3). Despite large differences in leaf gas exchange and morphological characteristics, FE and SL species display non-significantly different $\Delta$, WUE and $C$ values, whereas species with the lowest $\Delta$ (highest WUE) have an intermediate position along the successional gradient. The lowest $\Delta$ (i.e. highest WUE and low $\mathrm{g}_{\mathrm{s}}$ ) observed for these species might be associated with a better ability to compete under high water vapour pressure deficit $[2,34]$ such as in the upper canopy layer, and/or under low soil water conditions $[12,31,33,41]$ such as during the seasonal dry season encountered in French Guiana [25]. Whether this peculiar 'V shaped' pattern of relationship between $\Delta$ and the position within the successional gradient of species holds in other forest biomes is a worthy question. 
Acknowledgements: The authors wish to express their deep thanks to Jean-Yves Goret and Elli Lentilus, INRA Kourou, for their precious contribution to this experiment, to Chris Baraloto who provided the seedlings, and Tancrede Almeras for his help in the data analysis. We also thank two anonymous reviewers who greatly enhanced the first manuscript.

\section{REFERENCES}

[1] Badeck F. W., Tcherkez G., Nogue S., Piel C., Ghashghaie J., Post-photosynthetic fractionation of stable carbon isotopes between plant organs - a widespread phenomenon, Rapid. Commun. Mass Spectrom. 19 (2005) 1381-1391.

[2] Barbour M.M., Farquhar G.D., Relative humidity- and ABAinduced variation in carbon and oxygen isotope ratios of cotton leaves, Plant Cell Environ. 23 (2000) 473-485.

[3] Bazzaz F.A., Picket S.T.A., Physiological ecology of a tropical succession: a comparative review, Annu. Rev. Ecol. Syst. 11 (1980) 287-310.

[4] Béna P., Essences forestières de Guyane, Imprimerie Nationale, 1960.

[5] Boggan J., Funk V., Kelloff C., Hoff M., Cremers G., Feuillet C., Checklist of the plants of the Guianas: Guiana, Surinam, French Guiana, Georgetown, Guyana, 1997.

[6] Bonal D., Barigah T.S., Granier A., Guehl J.-M., Late stage canopy tree species with extremely low $\delta^{13} \mathrm{C}$ and high stomatal sensitivity to seasonal soil drought in the tropical rainforest of French Guiana, Plant Cell Environ. 23 (2000) 445-459.

[7] Bonal D., Sabatier D., Montpied P., Tremeaux D., Guehl J.M., Interspecific variability of $\delta^{13} \mathrm{C}$ among canopy trees in rainforests of French Guiana: Functional groups and canopy integration, Oecologia 124 (2000) 454-468.

[8] Caemmerer S. von, Farquhar G.D., Some relationships between the biochemistry of photosynthesis and the gas exchange rates of leaves, Planta 153 (1981) 376-387.

[9] Cao K.F., Water relations and gas exchange of tropical saplings during a prolonged drought in a Bornean heath forest, with reference to root architecture, J. Trop. Ecol. 16 (2000) 101-116.

[10] Coste S., Roggy J.-C., Imbert P., Born C., Bonal D., Dreyer E., Leaf photosynthetic traits of 14 tropical rain forest species in relation to leaf nitrogen concentration and shade tolerance, Tree Physiol. 25 (2005) 1127-1137.

[11] Covone F., Gratani L., Age-related physiological and structural traits of chestnut coppices at the Castelli Romani park (Italy), Ann. For. Sci. 63 (2006) 239-247.

[12] Cowan I.R., Economics of carbon fixation in higher plants, in: Givnish T.J. (Ed.), On the economy of plant form and function, Cambridge University Press, Cambridge, 1986, pp. 133-170.

[13] Ehleringer J.R., Gas exchange implications of isotopic variation in arid-land plants, in: Smith J.A.C., Griffiths H. (Eds.), Water deficits. plant responses from cell to community, Environmental Plant Biology Series, Lancaster, UK, 1993, pp. 265-284.

[14] Ehleringer J.R., Hall A.E., Farquhar G.D., Stable isotopes and plant-carbon water relations, Academic Press Inc., 1993.

[15] Ellis A.R., Hubbell S.P., Potvin C., In situ field measurements of photosynthetic rates of tropical tree species: a test of the functional group hypothesis, Can. J. Bot. 78 (2000) 1336-1347.

[16] Ellsworth D.S., Reich P.B., Photosynthesis and leaf nitrogen in five Amazonian tree species during early secondary succession, Ecology 77 (1996) 581-594.

[17] Engelbrecht B.M.J., Wright S.J., De Steven D., Survival and ecophysiology of tree seedlings during El Nino drought in a tropical moist forest in Panama, J. Trop. Ecol. 18 (2002) 569-579.
[18] Evans J.R., Sharkey T.D., Berry J.A., Farquhar G.D., Carbon isotope discrimination measured concurrently with gas exchange to investigate $\mathrm{CO}_{2}$ diffusion in leaves of higher plants, Aust. J. Plant Physiol. 13 (1986) 281-292.

[19] Farquhar G.D., O'Leary M.H., Berry J.A., On the relationship between carbon isotope discrimination and the intercellular carbon dioxide concentration in leaves, Aust. J. Plant Physiol. 9 (1982) 121-137.

[20] Farquhar G.D., Ehleringer J.R., Hubick K.T., Carbon isotope discrimination and photosynthesis, Annu. Rev. Plant Physiol. 40 (1989) 503-537.

[21] Farquhar G.D., Hubick K.T., Condon A.G., Richards R.A., Carbon isotope fractionation and plant water-use efficiency, in: Rundel P.W. Ehleringer J.R., Nagy K.A. (Eds.), Stable isotopes in ecological research, Springer-Verlag, New York, 1989, pp. 21-40.

[22] Favrichon V., Classification des espèces arborées en groupes fonctionnels en vue de la réalisation d'un modèle de dynamique de peuplement en forêt Guyanaise, Rev. Ecol. (Terre Vie) 49 (1994) 379403.

[23] Favrichon V., Modèle matriciel déterministe en temps discret : application à l'étude de la dynamique d'un peuplement forestier tropical humide (Guyane française), Ph.D. thesis, Université Claude Bernard-Lyon I, 1995.

[24] Favrichon V., Apports d'un modèle démographique plurispécifique pour l'étude des relations diversité / dynamique en forêt tropicale guyanaise, Ann. For. Sci. 55 (1998) 655-669.

[25] Guehl J.-M., Dynamique de l'eau dans le sol en forêt tropicale humide guyanaise. Influence de la couverture pédologique, Annu. For. Sci. 41 (1984) 195-236.

[26] Guehl J.-M., Bonal D., Ferhi A., Barigah T.S., Farquhar G.D., Granier A., Community-level diversity of carbon-water relations in rainforest trees, in: Gourlet-Fleury S., Laroussini O., Guehl J.M. (Eds.), Ecology and management of a neotropical rainforest, Paracou (French Guiana), Elsevier, Paris, 2004, pp. 65-84.

[27] Gyenge J.E., Fernández M.E., Salda G.D., Schlichter T., Leaf and whole-plant water relations of the Patagonian conifer Austrocedrus chilensis (D. Don) Pic. Ser. et Bizzarri: implications on its drought resistance capacity, Ann. For. Sci. 62 (2005) 297-302.

[28] Hanba Y.T., Wada E., Osaki M., Nakaruma T., Growth and $\delta^{13} \mathrm{C}$ responses to increasing atmospheric carbon dioxide concentrations for several crop species, Isotopes Environ. Health Stud. 32 (1996) $41-54$.

[29] Hogan K.P., Smith A.P., Samaniego M., Gas exchange in six tropical semi-deciduous forest canopy tree species during the wet and dry seasons, Biotropica 27 (1995) 324-333.

[30] Huc R., Ferhi A., Guehl J.-M., Pioneer and late stage tropical rainforest tree species (French Guyana) growing under common conditions differ in leaf gas exchange regulation, carbon isotope discrimination and leaf water potential, Oecologia 99 (1994) 297-305.

[31] Jones H.G., Drought tolerance and water-use efficiency, in: Smith J.A.C., Griffiths H. (Eds.), Water deficits. plant responses from cell to community, Environmental Plant Biology Series, Lancaster, UK, 1993, pp. 193-203.

[32] Kitajima K., Relative importance of photosynthetic traits and allocation patterns as correlates of seedling shade tolerance of 13 tropical trees, Oecologia 98 (1994) 419-428.

[33] Le Roux D., Stock W.D., Bond W.J., Maphanga D., Dry mass allocation, water use efficiency and $\delta^{13} \mathrm{C}$ in clones of Eucalyptus grandis, $E$. grandis $\times$ camaldulensis and $E$. grandis $\times$ nitens grown under two irrigation regimes, Tree Physiol. 16 (1996) 497-502.

[34] Madhavan S., Treichel I.W., O’Leary M.H., Effects of relative humidity on carbon isotope fractionation in plants, Bot. Acta 104 (1991) 292-294.

[35] Marino B.D., Mc Elroy M.B., Isotopic composition of atmospheric $\mathrm{CO}_{2}$ inferred from carbon in $\mathrm{C}_{4}$ plant cellulose, Nature 349 (1991) $127-131$. 
[36] McConnaughay K.D.M., Coleman J.S., Biomass allocation in plants: ontogeny or optimality? A test along three resource gradients, Ecology 80 (1999) 2581-2593.

[37] Meinzer F.C., Goldstein G., Holbrook N.M., Jackson P., Cavelier J., Stomatal and environmental control of transpiration in a lowland tropical forest tree, Plant Cell Environ. 16 (1993) 429-436.

[38] Naeem S., Wright J.P., Disentangling biodiversity effects on ecosystem functioning: deriving solutions to a seemingly insurmountable problem, Ecol. Lett. 6 (2003) 567-579.

[39] Oldeman R.A.A., van Dijk J., Diagnosis of the temperament of tropical rain forest trees. Rain forest regeneration and management, in: Gomez-Pompa A., Whitmore T.C., Hadley M. (Eds.), Rain forest regeneration and management, Unesco, Paris, 1991, pp. 21-65.

[40] Parkhurst D.F., Diffusion of $\mathrm{CO}_{2}$ and other gases inside leaves, New Phytol. 126 (1994) 449-479.

[41] Picon C., Guehl J.-M., Ferhi A., Leaf gas exchange and carbon isotope discrimination responses to drought in a drought-avoiding (Pinus pinaster) and a drought-tolerant (Quercus petraea) species under present and elevated atmospheric $\mathrm{CO}_{2}$ concentration, Plant Cell Environ. 19 (1996) 182-190.

[42] Poorter L., Kwant R., Hernández R., Medina E., Werger M.J.A., Leaf optical properties in Venezuelan cloud forest trees, Tree Physiol. 20 (2000) 519-526.

[43] Reich A., Holbrook N.M., Ewel J.J., Developmental and physiological correlates of leaf size in Hyeronima alchorneoides (Euphorbiaceae), Am. J. Bot. 91 (2004) 582-589.

[44] Reich P.B., Walters M.B., Ellsworth D.S., Uhl C., Photosynthesisnitrogen relations in Amazonian tree species. I: Patterns among species and communities, Oecologia 97 (1994) 62-72.

[45] Reich P.B., Walters M.B., Ellsworth D.S., From tropics to tundra: Global convergence in plant functioning, Proc. Nat. Ac. Sci. 94 (1997) 13730-13734.

[46] Reich P.B., Ellsworth D.S., Walters M.B., Vose J.M., Gresham C., Volin J.C., Bowman W.D., Generality of leaf trait relationships: a test across six biomes, Ecology 80 (1999) 1955-1969.

[47] Ricklefs R.E., Environmental heterogeneity and plant species diversity: a hypothesis, Amer. Nat. 111 (1977) 377-381.

[48] Shipley B., Lechowicz M.J., Wright I., Reich P.B., Fundamental tradeoffs generating the worldwide leaf economics spectrum. Ecology 87 (2006) 535-541.

[49] Strauss-Debenedetti S., Bazzaz F.A., Photosynthetic characteristics of tropical trees along successional gradients, in: Mulkey S.S.,
Chazdon R.L., Smith P.A. (Eds.), Tropical Forest Plant Ecophysiology, Chapman and Hall, New York, 1996, pp. 162-186.

[50] Swaine M.D., Whitmore T.C., On the definition of ecological species groups in tropical rain forests, Vegetatio 75 (1988) 81-86.

[51] Tcherkez G., Nogués S., Bleton J., Cornic G., Badeck F., Ghashghaie J., Metabolic origin of carbon isotope composition of leaf dark-respired $\mathrm{CO}_{2}$ in French bean, Plant Physiol. 131 (2003) 237-244.

[52] Terwilliger V.J., Kitajima K., Le Roux-Swarthout D.J., Mulkey S.S., Wright S.J., Intrinsic water-use efficiency and heterotrophic investment in tropical leaf growth of two neotropical pioneer tree species as estimated from delta C-13 values, New Phytol. 152 (2001) 267281.

[53] Thomas S.C., Bazzaz F.A., Asymptotic height as a predictor of photosynthetic characteristics in Malaysian rain forest trees, Ecology 80 (1999) 1607-1622.

[54] Tobin M.F., Lopez O.R., Kursar T.A., Responses of tropical understory plants to a severe drought: tolerance and avoidance of water stress, Biotropica 31 (1999) 570-578.

[55] Turner I., The Ecology of trees in the tropical rain forest, Cambridge Tropical Biology Series, University Press, Cambridge, 2001.

[56] Wright I.J., Reich P.B., Westoby M., Ackerly D.D., Baruch Z., Bongers F., Cavender-Bares J., Chapin T., Cornelissen J.H.C., Diemer M., Flexas J., Garnier E., Groom P.K., Gulias J., Hikosaka K., Lamont B.B., Lee T., Lee W., Lusk C., Midgley J.J., Navas M.L., Niinemets U., Oleksyn J., Osada N., Poorter H., Poot P., Prior L., Pyankov V.I., Roumet C., Thomas S.C., Tjoelker M.G., Veneklaas E.J., Villar R., The worldwide leaf economics spectrum, Nature 428 (2004) 821-827.

[57] Wright I.J., Reich P.B., Cornelissen J.H.C., Falster D.S., Garnier E., Hikosaka K., Lamont B.B., Lee W., Oleksyn J., Osada N., Poorter H., Villar R., Warton D.I., Westoby M., Assessing the generality of global leaf trait relationships, New Phytol. 166 (2005) 485-496.

[58] Wright S.J., Plant diversity in tropical forests: a review of mechanisms of species coexistence, Oecologia 130 (2002) 1-14.

[59] Xu Z.H., Saffigna P.G., Farquhar G.D., Simpson J.A., Haines R.J., Walker S., Osborne D.O., Guinto D., Carbon isotope discrimination and oxygen isotope composition in clones of the F1 hybrid between slash pine and Caribbean pine in relation to growth, water-use efficiency and foliar nutrient concentration, Tree Physiol. 20 (2000) 1209-1218. 